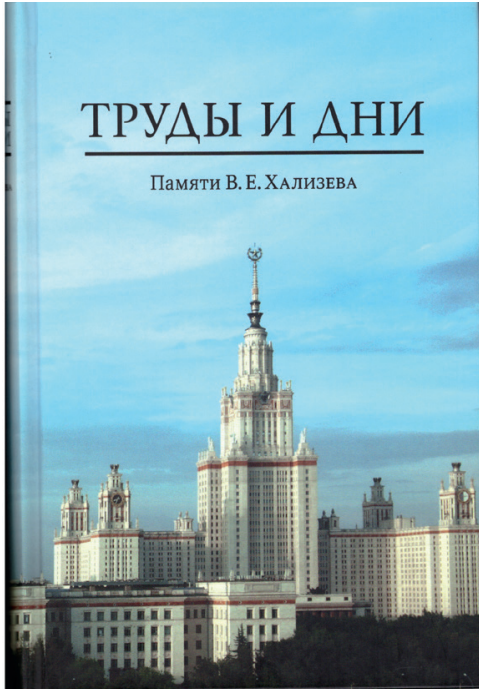

Сборник / Под ред. О.А. Клинга, С.А. Мартьяновой, О.В. Никандровой, Л.В. Чернец (отв. ред.). Москва: МАКС Пресс, 2017. 448 с.

T.Ya. Orlova (Moscow, Russia)

\title{
Works and Days. In Memory of V.E. Khalizev: A Collection of Articles / Eds.: O.A. Kling, S.A. Mart'yanova, O.V. Nikandrova, L.V. Chernets (ed.-in-chief). Moscow: MAKS Press, 2017. 448 p.
}

Сборник, посвященный памяти Валентина Евгеньевича Хализева (1930-2016), теоретика и историка литературы, заслуженного профессора МГУ имени М.В. Ломоносова, - издание во многом уникальное, так как включает не только подборку научных статей, разнообразных по тематике и проблематике, но ряд чрезвычайно интересных материалов из семейного архива В.Е. Хализева и воспоминания о нем коллег и учеников. Публикуется несколько фрагментов из хроники семьи ученого, которая создавалась им, как предполагает подготовивший материалы к изданию С.В. Хализев, с 1970-х гг. В основе этой хроники беседы Валентина Евгеньевича с родственниками, работа с архивом семьи Хализевых. Раздумья о прошлом помогли ему, как он сам написал в послесловии к хронике, почувствовать связь между изучением своей семейной истории и профессиональной деятельностью: «Со временем уяснилась связь между этой гранью моей работы и всем иным, что я делал (на протяжении тех же двадцати лет) и пытаюсь продолжать сейчас: публикации о пушкинских "Евгении Онегине", "Повестях Белкина", “Капитанской дочке”, “Борисе Годунове", о "Войне и мире", о Лескове, а также о нашем XX веке (А.А. УХтомский, М.А. Золотарев и Н.С. Арсеньев, М.М. Пришвин и А.А. Мейер, М.М. Бахтин и В.М. Жирмунский)» (стр. 13).

И то, и другое, поясняет он далее свое суждение, объединено общей мыслью о судьбе нашей страны и о русском менталитете. Это пояснение помогает понять, в чем была притягательность личности Валентина Евгеньевича, чему подтверждением служат опубликованные в сборнике воспоминания тех, кто на протяжении долгих лет поддерживал с ним дружеские отношения (воспоминания составили вторую часть книги). Понятно становится, в чем особенность его работ по теории и истории литературы: все его «академические» штудии имеют несколько изме- 
рений, они не замкнуты в сухом предметном анализе, но отражают разные грани русской цивилизации.

Новые штрихи к личности В.Е. Хализева добавлены публикацией «Устных мемуаров»- записанных С.В. Хализевым бесед с отцом, как и включенным в сборник интервью («Я - маргинал...», 2001 г.) с интересным предисловием интервьюера, Г.В. Зыковой. Вошли в первую часть книги, где собраны тексты В.Е. Хализева, его «теоретические размышления» - «Искусство мизансцены» и несколько писем (с предисловиями, послесловиями и, в ряде случаев, примечаниями) адресатов.

Третья часть сборника - статьи, в которых исследуются разные аспекты истории и теории литературы, и само их разнообразие, при том что все они тематически перекликаются с работами В.Е. Хализева, помогает представить масштаб и характер научной деятельности ученого. Авторы ряда статей обратились к творчеству Пушкина (А.М. Гуревич, «“В вековом прототипе...” (К истолкованию "Пира во время чумы” А.С. Пушкина»; В.И. Коровин, «О мотиве чаши в "Моцарте и Сальери" А.С. Пушкина») - с ней перекликается, расширяя проблематику, статья Е.Г. Рудневой «О смысле трансисторического символа Чаши в русской литературе») и истории пушкиноведения (Д.П. Ивинский, «Из истории пушкиноведения: С.М. Бонди и Вяч.И. Иванов»).

Проблемы психологии творчества, специфика восприятия художественных произведений критиками и читателями, отношение автора к создаваемому им тексту эти сложные вопросы авторы статей решают на материале творчества писателей разных эпох: Ф.М. Достоевского (В.А. Котельников, “"Истина” у Ф.М. Достоевского и М. Хайдеггера») и Ф. Сологуба (О.В. Никандрова, «Отсутствие катарсиса как черта неклассической картины мира в романе Ф. Сологуба “Мелкий бес"»), И. Бродского (Л.А. Колобаева, «Язык, речь и смысл в эстетике И. Бродского») и А. Грина (А.А. Ревякина, «“Скульптура души...”: А.С. Грин о психологии творчества»). В этом же контексте рассматриваются позиция Н.Д. Ахшарумова-критика (Н.В. Володина, «Читатель в литературной критике Н.Д. Ахшарумова») и литературно-критическое творчество С.Н. Дурылина (И.В. Мотеюнайте, «Наука или литература: исследовательские стратегии С.Н. Дурылина»).

Есть в сборнике статьи, посвященные частным вопросам русской драматургии (И.Н. Исакова, «Имена персонажей в пьесе А.Н. Островского "Не так живи, как хочется" в контексте народной культуры»; С.А. Мартьянова, «Речевое поведение персонажей пьесы А.П. Чехова "Чайка"»), а также статьи, в которых авторы обращаются к проблемам общего (Б.Ф. Егоров, «Патриотизм и любовь») и теоретико-литературного характера (О.А. Клинг, «Культурная память сатиры»; Л.В. Чернец, «О темпах повествования в эпических произведениях»). Специфика сюжетного повествования в эпосе на примере бунинской «Старухи» представлена в статье В.Б. Семенова («Сюжетность, или Как построена “Старуха” Бунина»).

Авторы других статей анализируют типологию героев русской литературы, обнаруживая связь разных литературных эпох (П.С. Глушаков, «“Как-нибудь включиться в народную жизнь” (Аксиологические поиски М. Горького и В.М. Шукшина)»), исследуя «сквозные» образы русской литературы (Г.И. Романова, «Странники в русской литературе и их типология») или обращаясь к типажу героя у конкретного автора (В.И. Тюпа, «Чеховский герой: между характером и самостью»).

Наряду с ними есть статьи, в которых речь идет о современных тенденциях в литературе и литературоведении (М.Н. Эпштейн, «Текстоника. Об электронных текстах и их конфигурациях»; В.В. Курилов, «Металитературоведение: о форми- 
ровании понятия в русской науке»), о применении законов литературных жанров в журналистике (В.В. Прозоров, «Телевидение как явление драмы»).

Заинтересуют читателя фотоматериалы, представленные в книге, и, конечно же, «Список трудов В.Е. Хализева» (составлен О.В. Никандровой), включающий более 300 наименований.

Сведения об авторе:

Татьяна Яковлевна Орлова,

канд. филол. наук

ст. научный сотрудник

филологический факультет

МГУ имени М.В. Ломоносова
Tatiana Ya. Orlova,

$\mathrm{PhD}$

Senior Researcher

Philological Faculty

Lomonosov Moscow State University

orlova.t.y@yandex.ru 